ROCZNIKI TEOLOGICZNE

Tom LXVI, zeszyt 1 - 2019

DOI:http://dx.doi.org/10.18290/rt.2019.66.1-4

BEATA SZLUZ

\title{
OPIEKA NAD OSOBĄ Z CHOROBĄ PARKINSONA W PERCEPCJI OPIEKUNA RODZINNEGO
}

\author{
CARING FOR A PERSON WITH PARKINSON'S \\ IN THE PERCEPTION OF A FAMILY CAREGIVER
}

\begin{abstract}
A b s t r a c t. Because of the aging societies the increased prevalence of patients with dementia is observed. Parkinson's disease is one of the most frequent neurodegenerative disorders and occurs mainly in people in age over 50 years. The core symptoms of Parkinson disease are bradykinesia, tremor and plastic rigidity. Caring for a person with Parkinson's disease is not only exhausting physically and emotionally, but can also have high financial costs. The paper aims to present difficulties encountered by family caregivers of people with Parkinson's disease. Caring for person with PD run the caregivers the high risk of decreased quality of life, it is especially true with regard to family caregivers who are emotionally related with the patient.
\end{abstract}

Key words: the sociology of social problems; the sociology of family; social problem; caring; family caregiver; Parkinson's disease.

Proces starzenia się społeczeństwa prowadzi do wzrostu liczby osób w wieku podeszłym, następuje zatem zwiększenie się liczby osób doświadczających chorób neurozwyrodnieniowych. Choroba przewlekła może mieć charakter postępujący, może nawet spowodować przedwczesny zgon. Według amerykańskiej Komisji ds. Chorób Przewlekłych (Commission on Chronic Illness) choroby przewlekłe są to: „wszelkie zaburzenia lub odchylenia od

Dr hab. BeATA SzLUZ, prof. UR - Uniwersytet Rzeszowski, Instytut Socjologii, Zakład Socjologii Problemów Społecznych; adres do korespondencji: Al. T. Rejtana 16 C, 35-959 Rzeszów; e-mail: bszluz@ur.edu.pl lub bszluz@poczta.fm; ORCID 0000-0003-2441-9175. 
normy, które mają jedną lub więcej z następujących cech charakterystycznych: są trwałe, pozostawiają po sobie inwalidztwo, spowodowane są nieodwracalnymi zmianami patologicznymi, wymagają specjalnego postępowania rehabilitacyjnego albo według wszelkich oczekiwań wymagać będą długiego okresu nadzoru, obserwacji czy opieki"1.

W Polsce w 2005 r. było 5,9 mln osób w wieku powyżej 60 roku życia. W 2030 r. ich liczba przekroczy 9 milionów. Diagnozowanie i terapia oraz opieka nad chorymi staje się zatem coraz większym wyzwaniem². Choroba Parkinsona występuje u około $0,15-0,3 \%$ populacji ogólnej. Powyżej 65 roku życia częstość jej występowania wzrasta, wynosi 1,5\%. Szacuje się, że choruje średnio 120-180 osób na 100 tys. mieszkańców. W Polsce żyje ok. 60-70 tys. chorych. Częściej chorują mężczyźni. Odnotowano, że początek choroby Parkinsona przypada na 60 rok życia, moga jednak chorować także osoby młodsze (nawet 30-, 40-letnie) ${ }^{3}$. Starzenie się społeczeństwa prowadzi zatem do zwiększania się liczby osób z chorobą Parkinsona.

Objawy i przebieg choroby Parkinsona stanowią obciążenie dla pacjentów i opiekunów. Opieka nad osobą chorą jest wyczerpująca fizycznie i psychicznie, a także obciążająca ekonomicznie. Opiekunowie rodzinni doświadczają wielu problemów: fizycznych, psychicznych, społecznych, finansowych ${ }^{4}$. $\mathrm{Z}$ perspektywy socjologicznej choroba przewlekła jest wiązana $\mathrm{z}$,zakłóceniami biograficznymi" ${ }^{5}$. Pełnienie roli opiekuna rodzinnego stwarza wysokie ryzyko obniżenia jakości życia. Może prowadzić do pojawienia się wyczerpania, wypalania, określanego w odniesieniu do opiekunów jako „zespół wypa-

\footnotetext{
${ }^{1}$ F.C. SHONTZ, Ciężkie choroby przewlekte, w: Praktyka psychologiczna w rehabilitacji inwalidów, red. J.F. Garrett, E.S. Levine, tłum. Z. Obniski, Wydawnictwo Lekarskie PZWL, Warszawa 1972, s. 300.

${ }^{2}$ Por. R.J. Kalaria, G.E. Maestre, R. Arizaga i in., Alzheimer's disease and vascular dementia in developing countries: prevalence, management and risk factors, „The Lancet Neurology" 2008, nr 7, s. 812-826.

${ }^{3}$ Por. J. SŁAWEK, Choroba Parkinsona, https://neurologia.mp.pl/choroby/ 151060,chorobaparkinsona (30.07.2018).

${ }^{4}$ K. de Walden-GaŁuszKo, Psychospoteczne aspekty opieki paliatywnej, w: Podstawy opieki paliatywnej, red. K. de Walden-Gałuszko, Wydawnictwo Lekarskie PZWL, Warszawa 2004, s. 164-166.

${ }^{5}$ M. BURY, Health and Illness in a Changing Society, Routledge, London 1997, s. 124. „Zakłócenie biograficzne” występuje u chorego i opiekuna rodzinnego. Zob. B. SzLUZ, „Samoorganizowanie troski" - opieka nad osoba z choroba Alzheimera w biografii opiekuna rodzinnego, „Zeszyty Pracy Socjalnej” 2017, nr 3, s. 225-236.
} 
lenia opiekuna"6. W artykule podjęto próbę ukazania doświadczeń i problemów, które napotykają opiekunowie rodzinni osób z chorobą Parkinsona.

\section{SPECYFIKA CHOROBY PARKINSONA}

Pierwszego opisu choroby dokonał James Parkinson w 1817 r. (An Essay on the Shaking Palsy ${ }^{7}$ ). Początkowo w literaturze stosowano termin „drżączka poraźna" (paralysis agitans), następnie Jean-Martin Charcot wprowadził określenie „choroba Parkinsona” (PD - Parkinson's disease). Zmiany biochemiczne, leżące u podstaw choroby, odkrył szwedzki laureat Nagrody Nobla, biochemik Arvid Carlsson ${ }^{8}$. Choroba Parkinsona oznacza u pacjenta zwyrodnienie struktur mózgu, o nieznanej przyczynie.

W literaturze wskazano charakterystyczne objawy choroby Parkinsona. Należy do nich spowolnienie ruchowe nazywane również bradykinezją, a także co najmniej jeden z następujących objawów: wzmożone napięcie mięśniowe typu plastycznego, drżenie spoczynkowe lub/i zaburzenia postawy. Odnotowano także zaburzenia wegetatywne: ślinotok, łojotok, zaparcia. Zaobserwowano również zmianę charakteru pisma, tzw. mikrografię. Początek choroby moga poprzedzać (nawet o 10 lat) zaburzenia węchu i wspomniane zaparcia ${ }^{9}$. Do głównych objawów choroby należą: sztywność i wzmożone napięcie mięśniowe, drżenie spoczynkowe, spowolnienie ruchowe, zaburzenia mowy, objawy wegetatywne, zaburzenia funkcji poznawczych, a także objawy psychiatryczne.

Choroba Parkinsona jest schorzeniem postępującym. Pierwszy okres choroby trwa około 5 lat, nazywany jest „miodowym miesiącem”. Jest to czas,

\footnotetext{
${ }^{6}$ Szerzej zob. Domyopieki.pl, Zespót wypalenia opiekuna - jak rozpoznać i zapobiec, https://domyopieki.pl/artykuly/porady,237/zespol-wypalenia-opiekuna-\%E2\%80\%93-jak-rozpoznac-i-zapobiec,573.htm (4.08.2018).

7 J. PARKinson, An Essay on the Shaking Palsy, Printed by Whittingham and Rowland for Sherwood, Neely and Jones, London 1817.

${ }^{8}$ Zob. A. BJÖRKLUND, S.B. DunNETT, Dopamine neuron systems in the brain: an update, „Trends in Neurosciences” 2007, nr 5(30), s. 194-202.

${ }^{9}$ Por. A.J. Hughes, S.E. DANIEL, L. Kilford i in., Accuracy of clinical diagnosis of idiopathic Parkinson's disease: a clinico-pathological study of 100 cases, ,Journal Neurology Neurosurgery \& Psychiatry” 1992, nr 55, s. 181-184; A. GoRZKowSKA, B. JASIŃSKA-MYGA, G. OPALA, Kryteria rozpoznawania, różnicowanie, obraz kliniczny zaburzeń ruchowych oraz powiktania ruchowe późnego okresu choroby, w: Choroba Parkinsona i inne zaburzenia ruchowe, red. J. Sławek, A. Friedman, A. Bogucki, G. Opala, Wydawnictwo Via Medica, Gdańsk 2011, s. 118-125.
} 
w którym przyjmowanie leków daje dobre efekty. Postępujący ubytek komórek nerwowych, rozszerzanie się uszkodzeń na kolejne obszary mózgu, prowadzi do okresu zaawansowanego. Odpowiedź na leki w tym okresie jest jeszcze widoczna, ale słabsza i krótsza. Znacznie utrudnia to choremu codzienne funkcjonowanie, pogarsza się jakość jego życia, choroba prowadzi do różnych powikłań, np. spowodowanych upadkami. W tym okresie chory jest zwykle jeszcze samodzielny. Widoczne jest jednak stopniowe nasilanie się zaburzeń chodu (trudność w jego rozpoczęciu i nagłe zatrzymania). W ostatniej fazie choroby osoba chora spędza większość czasu na wózku lub w łóż$\mathrm{ku}^{10}$. Oznacza to pojawienie się zależności od opiekuna, wiążącej się z utratą samodzielności i niezależności w życiu codziennym.

\section{OPIEKA NAD CHORYM}

Zdzisław Dąbrowski zdefiniował opiekę międzyludzką, jest ona: „opartym na odpowiedzialności za podopiecznego, [...] ciągłym i bezinteresownym zaspokajaniem jego ponadpodmiotowych potrzeb w nawiązanym między nim a opiekunem zrównoważonym stosunku opiekuńczym"11. Wskazał jej cechy, do których zaliczył:

1. zaspokajanie ponadpodmiotowych potrzeb podopiecznego, czyli tych spośród całości jego potrzeb (powszechnych oraz indywidualnych - pozytywnych), których nie jest on w stanie (przejściowo lub trwale, częściowo lub całkowicie) samodzielnie zaspokoić i regulować;

2. ciągłość opieki, rozumiana jako cykliczne, permanentne troszczenie się o podopiecznego, zapewnianie mu poczucia bezpieczeństwa, stwarzanie mu optymalnych warunków życia i rozwoju;

3. bezinteresowność opieki, która wynika z dwóch przesłanek:

a) naturalnego i oczywistego podejmowania różnego rodzaju czynności opiekuńczych w każdym prawidłowo funkcjonującym środowisku rodzinnym w stosunku do krewnych, którzy potrzebują tego rodzaju pomocy, nie oczekując w zamian żadnych korzyści;

b) nastawienia na zaspokajanie $\mathrm{w}$ dynamicznym procesie opiekuńczym także różnego rodzaju potrzeb psychospołecznych, w tym także emocjonalnych podopiecznego, za które „niepodobna płacić opiekunom”;

\footnotetext{
${ }^{10}$ Por. J. SŁAwEK, Choroba Parkinsona.

11 Z. Dąbrowski, Pedagogika opiekuńcza $w$ zarysie, t. 1, Wydawnictwo Uniwersytetu Warmińsko-Mazurskiego, Olsztyn 2006, s. 87.
} 
4. stosunek opiekuńczy stanowiący mikrosystem, w którym zachodzi działalność opiekuńcza, na który składa się względnie trwały, specyficzny układ ról, pozycji, zależności i wymiany wartości między opiekunem a podopiecznym;

5. odpowiedzialność opiekuna za podopiecznego, stanowiąca kluczową, specyficzną cechę opieki związaną ze świadomym i dobrowolnym sprawowaniem wszelkich czynności opiekuńczych gwarantujących odpowiednią jakość życia podopiecznego oraz ponoszeniem za nie konsekwencji ${ }^{12}$.

Przytoczone za Z. Dąbrowskim cechy opieki międzyludzkiej powinny być widoczne w jej sprawowaniu w odniesieniu do osób doświadczających choroby Parkinsona. Stosunek opiekuńczy pomiędzy chorym a jego opiekunem ma charakter zindywidualizowany i rodzinny.

Znaczenie opieki pełnionej $\mathrm{w}$ rodzinie jest budowane $\mathrm{w}$ relacjach podopieczni i opiekunowie. Związki małżeńskie istnieją, aby służyć różnorodnym indywidualnym i rodzinnym funkcjom. $Z$ badań wynika, że opiekunowie rodzinni osób z chorobą Parkinsona opierają się na określaniu ich opiekunami prawdopodobnie dlatego, że termin ten zaczął oznaczać zależność i utratę wzajemności. Dla porównania, żaden z opiekunów rodzinnych osób z chorobą Alzheimera nie wahał się użyć tego terminu w odniesieniu do siebie. Zauważono, że kobiety częściej niż mężczyźni łączą satysfakcję małżeńską z ogólnym własnym samopoczuciem, dlatego są one w gorszej i trudniejszej sytuacji niż mężczyźni w scenariuszu opieki nad osobą z demencją, z powodu utraty wspomnianej wzajemności ${ }^{13}$.

Mając na uwadze deficyt badań, szczególnie w zakresie nauk społecznych, podjęto próbę opisu oraz interpretacji doświadczeń opiekunów rodzinnych

\footnotetext{
12 Zob. tamże, s. 82-83.

${ }^{13}$ Wyniki badań prowadzonych wśród opiekunów rodzinnych (np. Barush i Spaid; Fitting, Rabins, Lucas i Eastham; Gold, Franz, Reis i Senneville) wskazują, iż mężczyźni odczuwają mniej negatywnych skutków niż kobiety w zakresie zdrowia psychicznego i fizycznego, uczestnictwa w życiu społecznym i stabilności finansowej, opiekując się starszymi członkami rodziny. Badacze donosili, że kobiety zajmujące się opieką doświadczają wyższego poziomu obciążenia w porównaniu z opiekunami mężczyznami (np. Barush i Spaid; Gold i wsp.; Miller i Cafasso; Pruchno i Resch; Rose-Rego, Strauss, i Smyth) i wydają się być bardziej narażone na depresję (np. Collins, Stommel, Wang i Given; Dura, Haywood-Niler i Keicolt-Glaser; Fitting i wsp.; Pruchno i Resch; Stuckey, Neundorfer i Smyth). Różnice zgłaszane przez opiekunów płci męskiej i żeńskiej mogą wynikać z przyczyn metodologicznych, takich jak większy udział kobiet niż mężczyzn w większości badań (Miller; Miller i Cafasso) oraz mogą wiązać się z większą odpornością psychiczną wśród męskich opiekunów (Lutzky i Knight). Zob. K. HoOKer, M. Manoogian-O'Dell, D.J. Monahan, L.D. Frazier, K. Shifren, Does type of disease matter? Gender differences among Alzheimer's and Parkinson's disease spouse caregivers, „The Gerontologist” 2000, nr 5(40), s. 568-573.
} 
osób z chorobą Parkinsona. Głównym celem przeprowadzonego badania było poszukiwanie odpowiedzi na pytania o doświadczenia opiekunów rodzinnych oraz o zmianę zachowań ukierunkowanych na podejmowanie działań opiekuńczych. Poszukiwano odpowiedzi na pytania badawcze: jakie znaczenie nadaje badana jednostka treści swoich doświadczeń? Jaki wpływ na zmianę zachowań opiekuna miało podejmowanie działań opiekuńczych ukierunkowanych na osobę chorą?

Badanie zostało przeprowadzone w 2018 r. przez autorkę artykułu, z zastosowaniem techniki wywiadu pogłębionego (In-depth interview, IDI). Ze względu na ochronę danych osobowych nie podano miejsca przeprowadzenia wywiadów, usunięto nazwy miejscowości i inne nazwy własne. Liczba respondentów - 15, płeć - 8 mężczyzn (M) i 7 kobiet (K), wiek - od 40 do 80 lat. Autorka prowadzi także obserwację uczestniczącą od 8 lat.

Opiekun rodzinny pełni ważną rolę w życiu osoby z chorobą Parkinsona. W początkowym stadium choroby opiekun wspiera chorego i sporadycznie udziela mu pomocy. W późniejszym stadium, kiedy choroba pogłębia się, opiekun rodzinny pomaga chorej osobie w osobistych czynnościach, takich jak: mycie, ubieranie, jedzenie i podawanie leków.

„Choroba żony zaczęła się kilka lat temu. Może sześć, siedem. Ciągle uskarżała się, że bolą ją obojczyki, miała nawet jakieś zabiegi z użyciem lasera. Mówiła, że ją bolą plecy. Narzekała, że nie czuje smaków, ani zapachów. Miała ciagłe zaparcia. Wykonywała czynności w domu. Już nie pracowała, bo jako nauczycielka, przeszła na emeryturę $\mathrm{w}$ wieku pięćdziesięciu lat. Nie wymagała mojej opieki. [...] Stopniowo choroba się rozwijała. Żona była ciągle przygnębiona, nerwowa, a nawet agresywna. Przygnębienie narastało. [...] Obecnie żona wymaga już większej uwagi i wsparcia. Porusza się coraz wolniej, małymi kroczkami. Jej sylwetka pochyla się lekko do przodu. Ciągle narzeka na ból pleców, mięśni. Pociera rękami swoje nogi. Jest nie w pełni sprawna ruchowo. [...] Zdarzyło się, że upadła na schodach i bardzo się poobijała. [...] Woła mnie, żeby jej pomóc $\mathrm{w}$ wyjściu $\mathrm{z}$ wanny. Ja kupiłem i zamontowałem uchwyty i maty antypoślizgowe w łazience" (Mężczyzna 1, 77 lat).

„Choroba postępowała dosyć szybko. On leży, już nie może chodzić, bo nogi mu drżą i nie może stać, ani się ruszyć. Wożę go na wózku. Jest ciężki, dlatego z trudem przesuwam go na ten wózek. [...] Karmię go łyżeczką. Kupiłam też kubek ze specjalną pokrywką i taką wypustką do picia. [...] Ma problemy z połykaniem lekarstw. Krztusi się. Czasami się boję. [...] Trudne jest mycie. Pomaga mi siostra, bo sama nie daję sobie z nim rady. Jak jestem sama, to myję go na łóżku gąbką. Muszę sobie poradzić. Ubieram go w luźne dresy, bo jest najłatwiej" (Kobieta 2, 60 lat). 
Choroba Parkinsona jest progresywna, dlatego zmieniają się i pojawiaja nowe potrzeby u osoby chorej. Choroby przewlekłe prowadzą do konfrontowania jednostki i opiekuna z wyzwaniami. Chory doświadcza bólu, ograniczenia sprawności czy obawy utraty życia. Nie planuje przyszłości, odczuwa niepewność wynikającą z postawionej diagnozy i pomniejszenie własnych zasobów. Dokonuje się zmiana stylu życia, osoba staje się zależna od opieku$\mathrm{na}^{14}$. Opiekunowie rodzinni wchodzą w nową rolę. Przeorganizowują własne życie, które podporządkowane jest opiece. Jest ona coraz bardziej absorbująca dla jednostki. Następuje regres aktywności chorego i wzrost zależności od opiekuna. Istotne jest rozwijanie niezależności osoby chorej, nawet jeśli oznacza to dłuższe wykonywanie czynności przez opiekuna. Koncentrując się na osobie chorej, która skupia uwagę na sobie i napotykanych trudnościach, opiekun nie zaspokaja własnych potrzeb, co prowadzi do obniżania się jakości jego życia. Dobra komunikacja w rodzinie potrzebna jest zarówno choremu, jak i jego rodzinie oraz opiekunowi.

„Cały dzień jestem przy żonie. Ona już nie chodzi. Wożę ją na wózku. [...] Jestem zmęczony, mam czasami dość. Nie mam przyjaciół, bo nie chodzę do nikogo, ani nie zapraszam do siebie. Ja nawet nie mam czasu, bo tyle mam pracy przy żonie. [...] Lubiłem mecze, takie wiejskie, w których gra LZS, ale nie mogę iść. No już nic nie mogę. Nie wiem, czy ja jeszcze żyję? Nawet do lekarza trudno mi iść. Muszę prosić kogoś, aby z żoną został" (Mężczyzna 2, 80 lat).

„Opiekuję się ojcem od ośmiu lat. Nikt mi nie pomaga. [...] To duży problem dla mnie, bo nie mam z kim ojca zostawić. Myślę, że potrzebne są jakieś rozwiązania, żeby zastąpić, chociaż na chwilę osobę, która opiekuje się chorym. Mieszkam na wsi, pod średniej wielkości miastem, ale o niczym takim nie słyszałem. To by mi pomogło, żeby załatwić jakieś własne sprawy. Muszę w takiej sytuacji prosić, aby ktoś z ojcem chwilkę został" (Mężczyzna 3, 52 lata).

Zespół wypalenia opiekuna dotyczy osób, które sprawują opiekę nad osobą chorą lub niepełnosprawną, przy niedostatecznym wsparciu płynącym z otoczenia. Objawy obejmują: „(1) sferę fizyczną: zmniejszona odporność, bóle głowy, żołądka, podwyższone ciśnienie, zła dieta, używanie większej ilości tytoniu i kofeiny, bezsenność, wyczerpanie, długotrwałe poczucie zmęczenia; (2) sferę emocjonalną: zmienność nastrojów, ogólne przygnębienie, obniżenie

\footnotetext{
${ }^{14}$ Por. M. BISSCHOP, Chronic disease and depression: the modifying role of psychosocial resources, „Social Science and Medicine” 2004, nr 59, s. 721-733.
} 
samooceny, brak wiary w zmianę sytuacji, poczucie bezradności; (3) zachowanie: częste konflikty, obojętność wobec potrzeb podopiecznego, złe zarządzanie czasem, narzekanie, brak kreatywności, utrata umiejętności cieszenia się drobnymi przyjemnościami; (4) sferę postaw: przeświadczenie o własnej niekompetencji, obwinianie się, duży krytycyzm wobec swoich zachowań, pesymizm, znudzenie" 15 .

Rozwój „opieki wytchnieniowej” jest postulowany w naszym kraju, ale jednocześnie ciągle zbyt powolny ${ }^{16}$. Ma ona polegać na zapewnieniu opieki niepełnosprawnemu dziecku lub osobie dorosłej na czas, w którym nie może jej sprawować opiekun, np. z uwagi na zdarzenie losowe, potrzebę odpoczynku czy załatwienia codziennych spraw. Rozwijanie usług dziennych, podczas których podopieczny miałby szansę przebywać w innym otoczeniu, niż domowe, jest ważnym współcześnie zadaniem w zakresie polityki rodzinnej. Pobyty krótkoterminowe w specjalistycznych ośrodkach umożliwiają opiekunowi skorzystanie z odpoczynku, a dla seniora stwarzają szansę przebywania z osobami w podobnym wieku czy korzystania z zajęć usprawniających i rehabilitacji. Opiekun rodzinny ma możliwość podjęcia pracy (opieka nad chorym wielu opiekunom uniemożliwia podjęcie lub kontynuowanie zatrudnienia), załatwienia różnych spraw czy po prostu skorzystania z czasu wolnego.

„Potrzebne są ośrodki opieki dziennej. Mógłbym pracować, a przygotowani pracownicy opiekowaliby się i leczyli chorego. [...] Najtrudniej jest, kiedy chory już nie chodzi, bo potrzebuje ciągłej opieki innej osoby. Jest ciężko. Nawet za pieniądze trudno znaleźć kogoś do opieki. Pytałem różnych znajomych. [...] Sprawdziłem strony internetowe firm, w których można wynająć opiekuna. Nie stać mnie i koło się zamyka" (Mężczyzna 5, 53 lata).

Dostrzegana jest deprywacja potrzeb opiekunów i dezorganizacja ich życia codziennego. W zakres wsparcia opiekuna wpisuje się m.in.: przekazywanie informacji na temat choroby i sposobów pielęgnowania chorego, konsultowanie stanu zdrowia chorego ze specjalistami oraz zapewnienie odpowiedniego leczenia i rehabilitacji, a także opieki wyręczającej opiekuna ${ }^{17}$. Opiekunowi rodzinnemu przydatne są informacje, które pomogą w opiece nad chorym.

\footnotetext{
15 Domyopieki.pl

16 Szerzej na ten temat zob. Rynekseniora.pl, Nie ma $w$ Polsce prawdziwej opieki wytchnieniowej,http://www.rynekseniora.pl/rynek_opieki/105/nie_mamy_w_polsce_prawdziwej_opieki_wytchnieniowej,3491.html (3.11.2015); MRPiPS, Za życiem, https://www.mpips.gov.pl/ aktualnosci-wszystkie/swiadczenia-rodzinne/art,8783,za-zyciem-dla-rodzin.html (19.04.2017).

${ }^{17}$ Por. B. SzLuZ, Opieka nad osoba z choroba Alzheimera $w$ percepcji opiekuna rodzinnego, w: Praca socjalna wobec wyzwań wspótczesności, t. 3, red. E. Bojanowska, M. Kawińska, Wydawnictwo Kontrast, Warszawa 2017, s. 130.
} 
Respondenci zaznaczyli niedosyt informacji na temat choroby Parkinsona, akcentowali znaczenie działalności organizacji pozarządowych, które udzielały wsparcia informacyjnego, dostarczały ulotki, broszury i inne materiały, udzielały porad przez telefon, zamieszczały informacje na prowadzonych stronach internetowych.

„Mama ma zdiagnozowanego Parkinsona. Chodziła do kilku lekarzy, ale w końcu ja zapisałam ją do neurologa i zapadła diagnoza. [...] O chorobie niewiele powiedzieli. Ja szukałam informacji, głównie w Internecie. [...] Nikt nie wspomniał o wsparciu, pomocy, opiece. No nic. [...] Jest coraz gorzej, boję się, co ja zrobię? Wiem jedno, z pracy zawodowej nie zrezygnuję. Mam nadzieję, że może znajdę jakiś ośrodek opieki dziennej. Mam jednak obawy, czy ona zechce tam być? Chyba będziemy zmuszeni wybrać takie rozwiązanie. Wciąż szukam informacji o tej chorobie i pomocy. Ostatnio przeczytałam, że organizacja pozarządowa i parafia w mojej gminie prowadza jakiś program dla seniorów, w którym zapewniają opiekę dzienną" (Kobieta 3, 50 lat).

„Ciagle źle jest widziana pomoc społeczna. [...] Pracownik socjalny nie wspiera, nie ma właściwych rozwiązań w zakresie opieki na osobą starszą, chorą. Byłam w ośrodku pomocy społecznej. Nic nie zaoferowano. Smutne to i przerażające. [...] Organizacje pozarządowe lepiej działają" (Kobieta 3, 50 lat).

„Najwięcej informacji uzyskałam w stowarzyszeniu [...]. Dali mi kilka takich folderów o tej chorobie. Mąż je też przeczytał. On nie ma depresji, walczy $\mathrm{z}$ tą chorobą. $\mathrm{W}$ tych folderach było napisane, żeby na siłę spacerować, zmuszać się do spaceru, ruszać się, bo to pomaga. Dali wskazówki do chodzenia z kijkami, nordic walking. Mąż kupił kijki, chodzi z nimi codziennie. Myślę, że tylko dzięki temu jeszcze chodzi samodzielnie. [...] Dowiedzieliśmy się dużo o znaczeniu ruchu, diecie. Poznaliśmy lepiej chorobę" (Kobieta 1, 68 lat).

Organizacje stowarzyszające osoby z chorobą Parkinsona udzielają porad bądź wskazują źródła informacji dotyczące np. ulg finansowych, usług opiekuńczych, poradnictwa specjalistycznego, działania ośrodków pomocy społecznej i innych placówek pomocowych czy grup wsparcia itd. Umożliwiaja nawiązanie kontaktu z innymi chorymi osobami i ich opiekunami. Wymiana doświadczeń może pomóc w rozwiązaniu codziennych trudności.

„Problemem jest też reakcja opiekuna na oferowaną pomoc. Wstydzi się, męczy, ale nie chce pomocy. Czasami faktycznie czuje się spełniony, potrzebny, pomocny" (Mężczyzna 4, 40 lat).

Opiekun rodzinny jest znaczącym ogniwem w systemie opieki. Pełnienie roli opiekuna może związać się z poczuciem obciążenia bądź z mobilizowa- 
niem zasobów i modyfikacją sposobów działania, niektórzy bowiem w pełnieniu roli opiekuna rodzinnego postrzegają sens własnego życia.

Ważnym zadaniem dla chorego i opiekuna jest planowanie przyszłości. Osoba chora może komunikować, jak wyobraża sobie opiekę w zaawansowanym stadium choroby. Poprawa jakości życia chorego i opiekuna wiąże się zatem z koncentrowaniem się na tym, co można zrobić, a nie na tym, co jest niemożliwe. Zmiana dotychczasowej roli człowieka chorego może lokować go w nowym miejscu w rodzinie, co wiąże się z zaakceptowaniem tej zmiany.

\section{PODSUMOWANIE}

Choroba Parkinsona prowadzi do zmiany dotychczasowych ról w rodzinie. Osoba dotychczas niezależna, aktywna, sprawująca kontrolę i opiekę zaczyna funkcjonować w roli chorego. Staje się zależna od otoczenia, wymaga opieki i pomocy, stopniowo wycofuje się z dotychczasowych aktywności. Reakcja na nową sytuację zależy od osobowości sprzed okresu zachorowania, często jest to reakcja lękowa i depresyjna. Choroba jest doświadczeniem osób, które znajdują się blisko chorego. Rodzina i chory potrzebują wsparcia udzielanego przez specjalistów, m.in.: lekarzy, pielęgniarek, terapeutów, psychologów, psychoterapeutów, doradców zawodowych, pracowników socjalnych itd. Tylko część rodzin (nieliczni) umieszcza chorego w domach pomocy społecznej, w których uzyskują pomoc wykwalifikowanych opiekunów.

Opieka nad osobą chorą wymaga cierpliwości i wyrozumiałości. Opiekunowie rodzinni osób $\mathrm{z}$ chorobą Parkinsona doświadczają frustracji, poczucia osamotnienia, podkreślają potrzebę wyjścia z domu i odpoczynku. Z przeprowadzonych badań wynika, że część opiekunów rodzinnych odczuwa tzw. wypalenie sił. Doświadczają problemów emocjonalnych, fizycznych, zdrowotnych, społecznych i ekonomicznych. Ograniczony jest ich czas wolny, a także aktywność zawodowa. Opiekunowie rodzinni, zapewniając opiekę w domu, rzadko korzystają z pomocy instytucji (niekiedy decydują się na płatne usługi w domu). Nasuwa się wniosek, iż niezbędne jest rozwijanie ośrodków opieki dziennej, umożliwiającej pozostawanie w miejscu zamieszkania, a także form wsparcia chorych i opiekunów rodzinnych. Rodzina jest bowiem najważniejszym ogniwem w zakresie udzielania pomocy, opieki i wsparcia osobie chorej. 


\section{BIBLIOGRAFIA}

BISSCHOP M., Chronic disease and depression: the modifying role of psychosocial resources, „Social Science and Medicine” 2004, nr 59, s. 721-733.

BJÖRKLUND A., DunNETT S.B., Dopamine neuron systems in the brain: an update, „Trends in Neurosciences" 2007, nr 5(30), s. 194-202, DOI:10.1016/j.tins. 2007.03.006.

BURY M., Health and Illness in a Changing Society, Routledge, London 1997.

DĄBROWSKi Z., Pedagogika opiekuńcza w zarysie, t. 1, Wydawnictwo Uniwersytetu Warmińsko-Mazurskiego, Olsztyn 2006.

Domyopieki.pl, Zespół wypalenia opiekuna - jak rozpoznać i zapobiec, https://domyopieki.pl/artykuly/porady,237/zespol-wypalenia-opiekuna-\%E2\% 80\%93-jak-rozpoznac-i-zapobiec,573.htm (4.08.2018).

GoRZKowsKa A., JASIŃSKA-MYGa B., OpALA G., Kryteria rozpoznawania, różnicowanie, obraz kliniczny zaburzeń ruchowych oraz powikłania ruchowe późnego okresu choroby, w: Choroba Parkinsona i inne zaburzenia ruchowe, red. J. Sławek, A. Friedman, A. Bogucki, G. Opala, Wydawnictwo Via Medica, Gdańsk 2011, s. 118-125.

Hooker K., Manoogian-O’Dell M., Monahan D.J., Frazier L.D., Shifren K., Does type of disease matter? Gender differences among Alzheimer's and Parkinson's disease spouse caregivers, „The Gerontologist” 2000, nr 5(40), s. 568-573, DOI:10.1093/geront/40.5.568.

Hughes A.J., Daniel S.E., Kilford L. i in., Accuracy of clinical diagnosis of idiopathic Parkinson's disease: a clinico-pathological study of 100 cases, „Journal Neurology Neurosurgery \& Psychiatry" 1992, nr 55, s. 181-184.

Kalaria R.J., Maestre G.E., ARIZaga R. i in., Alzheimer's disease and vascular dementia in developing countries: prevalence, management and risk factors, „The Lancet Neurology” 2008, nr 7, s. 812-826, DOI:10.1016/S1474-4422(08)70169-8.

MRPiPS, Za życiem, https://www.mpips.gov.pl/aktualnosci-wszystkie/swiadczenia-rodzinne/art, 8783,za-zyciem-dla-rodzin.html (19.04.2017).

PARKInSON J., An Essay on the Shaking Palsy, Printed by Whittingham and Rowland for Sherwood, Neely and Jones, London 1817.

Rynekseniora.pl, Nie ma w Polsce prawdziwej opieki wytchnieniowej, http:// www.rynekseniora.pl/rynek_opieki/105/nie_mamy_w_polsce_prawdziwej_opieki_wytchnieniowej,3491.html (3.11.2015).

SHONTZ F.C., Ciężkie choroby przewlekłe, w: Praktyka psychologiczna w rehabilitacji inwalidów, red. J.F. Garrett, E.S. Levine, tłum. Z. Obniski, Wydawnictwo Lekarskie PZWL, Warszawa 1972.

SŁAWEK J., Choroba Parkinsona, https://neurologia.mp.pl/choroby/151060,choroba-parkinsona (30.07.2018).

SzLUZ B., Opieka nad osobą z chorobą Alzheimera w percepcji opiekuna rodzinnego, w: Praca socjalna wobec wyzwań współczesności, t. 3, red. E. Bojanowska, M. Kawińska, Wydawnictwo Kontrast, Warszawa 2017, s. 121-133.

SzLuZ B., „Samoorganizowanie troski” - opieka nad osobą z chorobą Alzheimera w biografii opiekuna rodzinnego, ,Zeszyty Pracy Socjalnej” 2017, nr 3, s. 225-236.

WALDEN-GAŁusZKo DE K., Psychospołeczne aspekty opieki paliatywnej, w: Podstawy opieki paliatywnej, red. K. de Walden-Gałuszko, Wydawnictwo Lekarskie PZWL, Warszawa 2004, s. $164-194$. 


\section{OPIEKA NAD OSOBA Z CHOROBA PARKINSONA W PERCEPCJI OPIEKUNA RODZINNEGO}

St r e s z c z e n i e

Z uwagi na proces starzenia się społeczeństw, częstość występowania zespołów otępiennych stale wzrasta. Choroba Parkinsona jest jedną z najczęstszych chorób neurozwyrodnieniowych i dotyczy przede wszystkim pacjentów po 50. roku życia. Głównymi objawami choroby Parkinsona są zaburzenia w postaci spowolnienia ruchowego, drżenia spoczynkowego i wzmożenia napięcia mięśni typu plastycznego. Opieka nad osobą z chorobą Parkinsona jest nie tylko wyczerpująca fizycznie i psychicznie, ale także kosztowna. W pracy podjęto próbę ukazania trudności, z którymi spotykają się rodzinni opiekunowie osób z chorobą Parkinsona. Sprawowanie opieki nad osobą z chorobą Parkinsona stwarza wysokie ryzyko obniżenia jakości życia przede wszystkim opiekunów rodzinnych silnie związanych emocjonalnie z chorym.

Słowa kluczowe: socjologia problemów społecznych; socjologia rodziny; problem społeczny; opieka; opiekun rodzinny; choroba Parkinsona. 